\begin{tabular}{|c|l|}
\hline Title & $\begin{array}{l}\text { Effects of load fluctuations on treatment potential of a hy brid sub-surface flow constructed wetl and treating milking } \\
\text { parlor waste water }\end{array}$ \\
\hline Author(s) & Sharma, Pradeep Kumar; Takashi, Inoue; Kato, Kunihiko; letsugu, Hidehiro; Tomita, Kunihiko; Nagasawa, Tetsuaki \\
\hline Citation & $\begin{array}{l}\text { Ecological engineering, 57, 216-225 } \\
\text { https://doi.org/10.1016j.ecoleng.2013.04.031 }\end{array}$ \\
\hline Issue Date & 2013.08 \\
\hline Doc URL & http://hdl.handle.net/2115/53735 \\
\hline Type & article (author version) \\
\hline File Information & effects of load fluctuation_Pradeep et al.2013.pdf \\
\hline
\end{tabular}

Instructions for use 


\section{Effects of load fluctuations on treatment potential of a hybrid sub-surface flow constructed wetland treating milking parlor waste water}

Pradeep Kumar Sharma ${ }^{1,2}$, Inoue Takashi ${ }^{1}$, Kunihiko Kato ${ }^{3}$, Hidehiro letsugu ${ }^{4}$, Kunihiko Tomita ${ }^{5}$, Tetsuaki Nagasawa ${ }^{1}$

Pradeep Kumar Sharma ${ }^{1,2}$

(Affiliation address): ${ }^{1}$ Graduate School of Agriculture, Hokkaido University, N9, W9, Kita-ku, Sapporo, 060-8589, Japan.

(Present address): ${ }^{2}$ Department of Environment Science, Graphic Era University, 566/6, Bell Road, Clement Town, Dehradun, India, 248002. Email: pradeep2910@gmail.com

Inoue Takashi': Graduate School of Agriculture, Hokkaido University, N9, W9, Kita-ku, Sapporo, 060-8589, Japan.

Email: tino@env.agr.hokudai.ac.jp

Tetsuaki Nagasawa ${ }^{1}$ : Graduate School of Agriculture, Hokkaido University, N9 W9, Kita-ku, Sapporo, 060-8589, Japan.

Email: ngsw@env.agr.hokudai.ac.jp

Kunihiko Kato ${ }^{3}$ : National Agricultural Research Centre for Hokkaido Region,Hitsujigaoka-1,Toyohira-ku,Sapporo, 062-8555, Japan Email: katokuni@affrc.go.jp

Hidehiro letsugu ${ }^{4}$ : TUSK Co. Ltd., Hokkaido, Japan

Kunihiko Tomita ${ }^{5}$ : Town Office, Embetsu, Hokkaido, Japan 


\section{Corresponding Author:}

Dr. Pradeep Kumar Sharma (Assistant Professor)

Department of Environment Science, Graphic Era University, 566/6, Bell Road,

Clement Town, Dehradun, Uttarakhand, India , 248002

Email: pradeep2910@gmail.com

Talex: +91-9720625982, Fax: +91-135-2644025

\section{Abstract}

A hybrid sub-surface constructed wetland (CW) system consisting of 2 gravel filled vertical sub-surface (VFa \& VFb) beds, each $160 \mathrm{~m}^{2}$ in size planted with Phragmites australis and a sand filled horizontal sub-surface (HF) bed, $336 \mathrm{~m}^{2}$ in size, planted with rice was operated from 2007 to 2010 for treating milking parlor waste water in Hokkaido, Japan. Hybrid CW system received huge fluctuations in average yearly inlet loads for TSS (526.0 -1259 $\mathrm{mg} \mathrm{L}^{-1} \& 2.7-9.0$ $\left.\mathrm{g} \mathrm{m}^{-2} \mathrm{~d}^{-1}\right), \mathrm{BOD}_{5}\left(1,080-2,114 \mathrm{mg} \mathrm{L}^{-1} \& 8.4-14.4 \mathrm{~g} \mathrm{~m}^{-2} \mathrm{~d}^{-1}\right), \operatorname{COD}(1,962-7,085$ $\left.\mathrm{mg} \mathrm{L}^{-1} \& 14.5-50.0 \mathrm{~g} \mathrm{~m}^{-2} \mathrm{~d}^{-1}\right)$, TN $\left(116.0-243.0 \mathrm{mg} \mathrm{L}^{-1} \& 0.8-1.6 \mathrm{~g} \mathrm{~m}^{-2} \mathrm{~d}^{-1}\right)$, $\mathrm{NH}_{4}-\mathrm{N}\left(54.0-90.0 \mathrm{mg} \mathrm{L}^{-1} \& 0.40-0.64 \mathrm{~g} \mathrm{~m}^{-2} \mathrm{~d}^{-1}\right), \mathrm{TC}\left(1,022-2,215 \mathrm{mg} \mathrm{L}^{-1} \&\right.$ 6.0 - $\left.15.1 \mathrm{~g} \mathrm{~m}^{-2} \mathrm{~d}^{-1}\right)$, TP $\left(15.3-41.7 \mathrm{mg} \mathrm{L}^{-1} \& 0.11-0.28 \mathrm{~g} \mathrm{~m}^{-2} \mathrm{~d}^{-1}\right)$ during study period. Average yearly purification and removal rates were least fluctuated for TSS (95.7 - 99.4\%); moderately for $\mathrm{BOD}_{5}(86.1$ - 95.7\%), COD(87.5 - 96.1\%) and TC (79.5 - 91.3\%); highly for TN (72.6 - 90.6\%), $\mathrm{NH}_{4}-\mathrm{N}(62.9-85.3 \%)$ and TP (64.8 - 87.2\%). A sharp decrease in TP purification and removal rates were observed in 2008 due to sharp decrease in influent TP concentration in 2008 
compared to 2007. OTR values for VF(a), VF(b), HF bed and total system were observed as $21.7,19.3,4.8$ and $12.3 \mathrm{~g} \mathrm{O}_{2} \mathrm{~m}^{-2} \mathrm{~d}^{-1}$ respectively. Average $\mathrm{k}$ value of hybrid $\mathrm{CW}$ system for $\mathrm{BOD}_{5}, \mathrm{TN}, \mathrm{NH}_{4}-\mathrm{N}$ and TP during study period were 7.0 $\pm 1.8,7.4 \pm 3.3,5.6 \pm 4.1$ and $4.9 \pm 2.0 \mathrm{~m} \mathrm{yr}^{-1}$ respectively.

Average concentration of TSS, TP, TN and $\mathrm{NH}_{4}-\mathrm{N}$ in the final effluent for all years were below the discharge limit value of: $150 \mathrm{mg} \mathrm{L}^{-1}$ for TSS; $8 \mathrm{mg} \mathrm{L}^{-1}$ for $\mathrm{TP}, 60 \mathrm{mg} \mathrm{\textrm {L } ^ { - 1 }}$ for $\mathrm{TN}$ and $\mathrm{NH}_{4}-\mathrm{N}$. However, average $\mathrm{BOD}_{5}$ and COD concentrations could not meet the discharge limit value of $120 \mathrm{mg} \mathrm{L}^{-1}$ during 2007 and 2008.

Key words: Hybrid sub-surface constructed wetland; milking parlor wastewater; load fluctuation.

\subsection{Introduction}

Milking parlor's discharge nutrient-rich wastewater which has high potential of polluting surface and/or ground water. Most of times, this wastewater is either stored and irrigated onto land (Moir et al., 2005) or treated by conventional methods such as trickling filters, activated sludge process, anaerobic lagoon and aerated lagoons (Munavalli and Saler, 2009), however all these treatment methods are expensive. Thus, small-scale milking parlor owners often show no/ less interest in adopting any of these technologies. On the other hand, constructed wetlands (CWs) which are simple in design and operation as well as cost effective has been tested worldwide to treat different types of wastewater such as domestic, industrial, acid mine drainage, agricultural runoff 
and land fill leachate (Beutel, et al., 2009; Nyquist and Greger, 2009; Kadlec and Zmarthie, 2010; Serrano, et al., 2011; Vymazal, 2011).

Among the recent developments, hybrid sub-surface CWs are becoming more popular because of their higher treatment potential (Noorvee et al., 2005; Öövel, 2007; Tuszyñska and Obarska-Pempkowiak, 2008; Justin, 2009; Singh et al., 2009; Kato et al., 2010, 2013; Sharma et al., 2012; Serrano et al., 2011; Vymazal and Kröpfelova, 2011). The Performance of a CW is affected by a range of factors such as operational mode (loading rate, continuous or batchload) and environmental conditions (climate, season, temperature etc.) (Chazarenc, et al., 2007).

Hokkaido is the largest milk producing region in Japan and has 7,809 dairy farms and 1374 milking parlors. Most of these dairy farms in Hokkaido are small-scaled farms and discharge large volumes of wastewater everyday. This paper presents the effects of load fluctuations on the treatment efficiencies,

OTR and $k$ value of a real-scale hybrid sub-surface flow CW system constructed in Embetsu, Hokkaido in November, 2006 and operated for 3 years under high load fluctuations during milking parlor wastewater treatment.

\subsection{Materials and methods}

\subsection{Site description}

The hybrid sub-surface CWs consisting of three beds in series (VFa, VFb and $\mathrm{HF}$ ) is located at a privately owned dairy farm in Embetsu, Hokkaido ( $44^{\circ} 45^{\prime} \mathrm{N}$, $\left.141^{\circ} 48^{\prime} \mathrm{E}\right)$. VF beds were constructed in November 2006 according to design 
recommendations of Cooper $(1997 ; 2005)$. The bed sizes were determined using following equations:

$\mathrm{OTR}=\mathrm{Q} *\left\{\left(\mathrm{BOD}_{\text {In }}-\mathrm{BOD}_{\text {Out }}\right)+4.3^{*}\left(\mathrm{NH}_{4}-\mathrm{N}_{\mathrm{ln}}-\mathrm{NH}_{4}-\mathrm{N}_{\text {Out }}\right)\right\}^{*} 100 /$ Total area...(2.1)

OTR ( Oxygen transfer rate): $\mathrm{g} \mathrm{O}_{2} \mathrm{~m}^{-2}$ day $^{-1}$

$\mathrm{Q}$ (Flow rate): Influent Volume $\left(\mathrm{m}^{3}\right.$ day $\left.^{-1}\right) ;$ Total area:m²; $\mathrm{BOD}$ and $\mathrm{NH}_{4}-\mathrm{N}: \mathrm{mg} \mathrm{L}^{-1}$ OTR of beds were considered as follows(Cooper, 1997; 2005):

VF beds $=28 \mathrm{~g} \mathrm{O}_{2} \mathrm{~m}^{-2}$ day $^{-1}, \mathrm{HF}$ bed $=15 \mathrm{~g} \mathrm{O}_{2} \mathrm{~m}^{-2}$ day $^{-1}$

Limit loading rate (LLR) was calculated using following equation(Cooper, 1997; 2005):.

LLR $=$ Flow rate $(Q)$ * $\mathrm{BOD}_{\mathrm{In}}$ * 100/ Total area

$\operatorname{LLR}=25\left(\mathrm{~g} \mathrm{BOD}_{5} \mathrm{~m}^{-2}\right.$ day $\left.^{-1}\right)$ or $50\left(\mathrm{~g} \mathrm{COD}_{\mathrm{Cr}} \mathrm{m}^{-2} \mathrm{day}^{-1}\right)$

Area of HF bed was kept nearly equal to areas of both VF beds together so that both beds (VF \&HF) could equally contribute in treatment of wastewater.

\subsection{Filter material, bed}

depth, surface vegetation

The first, $\operatorname{VF}(\mathrm{a})$ and second,

VF(b) beds are vertical subsurface flow beds, each $160 \mathrm{~m}^{2}$ in area with a depth of $0.71 \mathrm{~m}$.

Both beds were gravel filled and planted with common reed

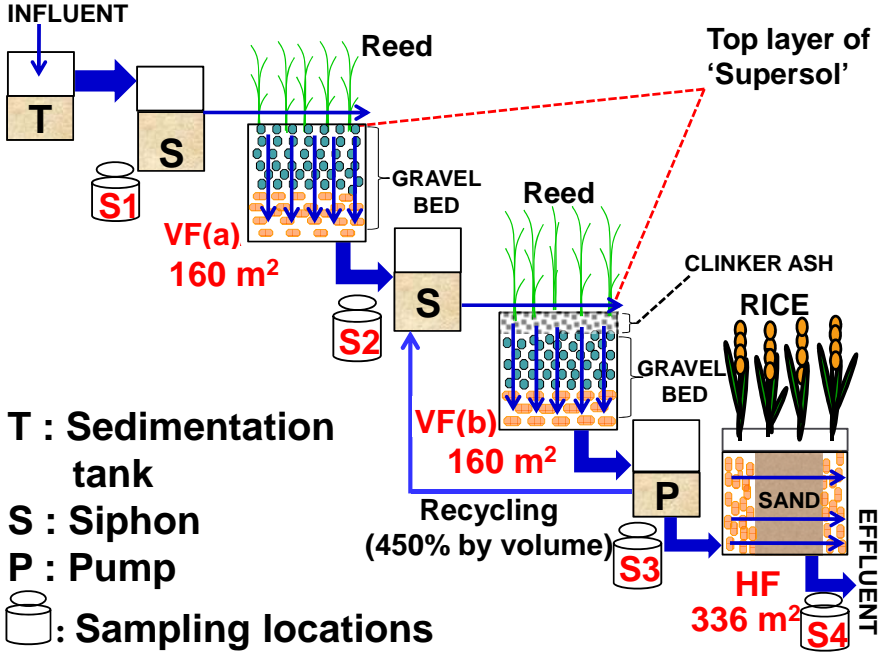

Fig.1: Schematic layout of Hybrid Sub-surface flow CW system at Embetsu, Hokkaido

(Phragmites australis). (Fig.1 \& Table 1). At the bottoms of both VF beds 
Table 1: Details of size, filter material and surface vegetation of hybrid sub-surface CWs at Embetsu. Hokkaido

\begin{tabular}{|c|c|c|c|c|c|c|c|}
\hline \multirow{2}{*}{$\begin{array}{l}\text { Name } \\
\text { of bed }\end{array}$} & \multirow{2}{*}{$\begin{array}{l}\text { Type of } \\
\text { bed }\end{array}$} & \multirow{2}{*}{$\begin{array}{l}\text { Area of } \\
\text { bed }\left(\mathrm{m}^{2}\right)\end{array}$} & \multicolumn{4}{|c|}{ Filter material } & \multirow[b]{2}{*}{ Surface Vegetation } \\
\hline & & & Position & Type & Size/density & $\begin{array}{l}\text { Thickness } \\
\text { (cm) }\end{array}$ & \\
\hline \multirow{4}{*}{$\operatorname{VF}(\mathrm{a})$} & \multirow{4}{*}{$\begin{array}{l}\text { Vertical } \\
\text { sub-surface }\end{array}$} & \multirow{3}{*}{160} & Top & Supersol & $0.4 \mathrm{~g} \mathrm{~cm}^{-3}$ & 5 & \multirow{3}{*}{ Phragmites australis } \\
\hline & & & Middle & Gravel & $5-15 \mathrm{~mm}$ & 30 & \\
\hline & & & Bottom & Gravel & $5-25 \mathrm{~mm}$ & 36 & \\
\hline & & & & & Total & 71 & \\
\hline \multirow{5}{*}{ VF(b) } & \multirow{5}{*}{$\begin{array}{l}\text { Vertical } \\
\text { sub-surface }\end{array}$} & \multirow{5}{*}{160} & Top & Supersol & $\begin{array}{l}0.4 \mathrm{~g} \mathrm{~cm}^{-3} \\
\mathrm{~d}_{10} \sim 0.06 \mathrm{~mm}\end{array}$ & 1 & \multirow{4}{*}{ Phragmites australis } \\
\hline & & & Upper middle & Clinker ash & $\begin{array}{l}\mathrm{d}_{60} \sim 1.5 \mathrm{~mm} \\
\mathrm{~d}_{60} / \mathrm{d}_{10} \sim 25\end{array}$ & 20 & \\
\hline & & & Lower middle & Gravel & $5-15 \mathrm{~mm}$ & 25 & \\
\hline & & & Bottom & Gravel & $5-25 \mathrm{~mm}$ & 25 & \\
\hline & & & & & Total & 71 & \\
\hline HF & $\begin{array}{l}\text { Horizontal } \\
\text { sub-surface }\end{array}$ & 336 & Top to bottom & Sand & $\begin{array}{l}\mathrm{d}_{10} \sim 0.25 \mathrm{~mm} \\
\mathrm{~d}_{60} \sim 0.49 \mathrm{~mm} \\
\mathrm{~d}_{60} / \mathrm{d}_{10} \sim 1.7\end{array}$ & 70 & $\begin{array}{l}\text { Rice }(2007,2008) \text {, } \\
\text { Phragmites australis } \\
(2009 \sim 2010)\end{array}$ \\
\hline
\end{tabular}

interconnected perforated pipes were placed to collect and drain the treated waste water from the beds. In VF(b) bed, recycling of effluent (450\%) from outlet tank (S3 location) to inlet tank (S2 location) was carried out during growing seasons of 2008, 2009 and 2010.

Third bed is HF bed, $336 \mathrm{~m}^{2}$ in area with a depth of $0.7 \mathrm{~m}$. HF bed was filled with washed sand from top to bottom. The bottoms of all three beds were built with a $1 \%$ slope, lined with high density polyethylene liner and circumferences of the beds were kept high to avoid seepage of waste water to underground water. In HF bed four different local varieties of forage rice were planted for assessing the nutrient recycling using nutrient uptake process of rice. Rice was planted in May month and harvested in October month in year 2007 and 2008. In August, 2009, supersole ${ }^{\circledR}$ was added on the HF bed surface $(0.05 \mathrm{~m}$ 
thickness) and planted with 300 reed plants. Supersol ${ }^{\circledR}$ is a porous material manufactured from recycled glass bottles (TRIM Co. Ltd.,2012).It has a low density of $0.4 \mathrm{~g} \mathrm{~cm}^{-3}$ due to which it floats on the bed surface during influent dosing and acts as an obstruction to the suspended solids (SS) of influent. This lead to uniform distribution of SS on the bed surfaces, which helps in preventing clogging of beds. Supersol $\circledast$ has an additional benefit of acting as an insulating material during cold winter and helps in preventing freezing conditions at the bed surfaces (Kato et al.,2013)

Dosing wastewater at VF beds was carried out using Siphon. In HF bed, an electric pump was used for dosing wastewater instead of siphon because of hydraulic limitations. Waste water was pretreated in a sedimentation tank (5.4 $\mathrm{m}^{3}$ ) for settling suspended solids.

\subsection{Sampling measurement and analysis}

Sampling was carried out from November 2006 to October 2010 at sampling locations S1, S2, S3, S4 (Fig.1). S1 is the inlet point and S4 is the final outlet point. Samples were collected once in a month, preserved and analyzed for TSS, COD $c r, \mathrm{BOD}_{5}$, total $\mathrm{N}(\mathrm{TN}), \mathrm{NH}_{4}-\mathrm{N}, \mathrm{NO}_{3}-\mathrm{N}$, total $\mathrm{P}(\mathrm{TP}), \mathrm{PO}_{4}-\mathrm{P}$, organic- $\mathrm{P}$, total coliform and total carbon (TC). DO, $\mathrm{pH}$, ORP and EC were measured at field during sampling.TSS was measured by suction filtration method (filtration at $45 \mu \mathrm{m}$ and drying at $\left.105^{\circ} \mathrm{C}\right)(\mathrm{APHA}, 1992)$. TN, and TC were measured using an elemental analyzer (Elementar vario MAX; Elementar Analysensysteme $\mathrm{GmbH}$, Hanau Germany) (Kato et al., 2013). $\mathrm{NH}_{4}-\mathrm{N}$, TP and 
$\mathrm{PO}_{4}-\mathrm{P}$ were measured by Spectrophotometric method ((APHA, 1992). $\mathrm{NO}_{3}-\mathrm{N}$ was measured by Ion Cromatograph(Shimadzu) (APHA, 1992). Total coliform was measured using Petrifilm plate count method(APHA, 1992). $\mathrm{BOD}_{5}$ was measured by 'JIS K 0121' method of Japanese Industrial standards (Kato et al.,2013). $\mathrm{COD}_{\mathrm{Cr}}$ was measured using 'HACH DR2800 portable spectrophotometer (Kato et al.,2013).

\subsection{Calculations of $k$ values, OTR, OTR and statistical analysis of data}

The removal of $\mathrm{BOD}_{5}, \mathrm{TP}, \mathrm{TN}$ and $\mathrm{NH}_{4}-\mathrm{N}$ in hybrid sub-surface $\mathrm{CWs}$ in Embetsu was also described using an area-based first-order model (later called the $\mathrm{k}-\mathrm{C}^{*}$ model) (Kadlec and knight, 1996; Kadlec, 2000):

$\ln \left[C_{0}-C^{*} / C_{i}-C^{*}\right]=-k / q$

Where $\mathrm{k}$ is the area-based, first-order rate-constant $\left(\mathrm{m} \mathrm{yr}^{-1}\right), \mathrm{q}$ the hydraulic loading rate $\left(\mathrm{m} \mathrm{yr}^{-1}\right), \mathrm{C}_{0}$ the effluent concentration $\left(\mathrm{mg} \mathrm{L}^{-1}\right), \mathrm{C}_{\mathrm{i}}$ the influent concentration ( $\mathrm{mg} \mathrm{L}^{-1}$ ) and $\mathrm{C}^{*}$ is the irreducible background wetland concentration $\left(\mathrm{mg} \mathrm{L}^{-1}\right)$.

Based on the published data (Kadlec and Knight, 1996), the $C^{*}$ values of $\mathrm{BOD}_{5}$ and TN were chosen as 1 and $1.5 \mathrm{mg} \mathrm{L}^{-1}$ respectively. It is well known that constructed wetlands have very low natural TP and $\mathrm{NH}_{4}-\mathrm{N}$ background concentrations. The $C^{*}$ values for these parameters are assumed to be 0.03 and $0.05 \mathrm{mg} \mathrm{L}^{-1}$ respectively (Kadlec and Knight, 1996).

Processes like ammonification, nitrification, and denitrification are temperature dependent. Therefore rates of $\mathrm{NH}_{4}-\mathrm{N}$ and $\mathrm{TN}$ reduction will also be temperature 
dependent (Kadlec, 2000). $\mathrm{K}_{\mathrm{T}}$ values need a conversion to $\mathrm{k}_{20}$ values for comparison. The relation between $\mathrm{k}_{\mathrm{T}}$ and $\mathrm{k}_{20}$ is the Arrhenius equation.

$\mathrm{k}_{\mathrm{T}}=\mathrm{k}_{20} \varnothing^{\mathrm{T}-20}$

Where $\mathrm{k}_{\mathrm{T}}$ is the reaction rate coefficient at temperature $\mathrm{T}\left({ }^{\circ} \mathrm{C}\right), \mathrm{k}_{20}$ is the reaction rate coefficient at $20^{\circ} \mathrm{C}, \varnothing$ is the temperature factor and $\mathrm{T}$ is the temperature $\left({ }^{\circ} \mathrm{C}\right)$.

An estimate of the temperature factor of ammonium oxidation is $\varnothing=1.04$ and for nitrogen reduction $\varnothing=1.05$ (Kadlec and Knight, 1996).

After calculating $\mathrm{k}$ values for all the parameters, the dependence of $\mathrm{k}$ on mass loading and removed rates $\left(\mathrm{g} \mathrm{m}^{-2} \mathrm{~d}^{-1}\right)$ was investigated.

OTR is a measure of atmospheric oxygen transferred into bed and utilized for aerobic degradation of organic matter as well as nitrification of ammonium nitrogen.

OTR' reflects measure of atmospheric oxygen, required for full degradation of organic matter and nitrification of ammonium nitrogen present in the wastewater. $\mathrm{OTR}^{\prime}$ can be calculated using following formula.

$\mathrm{OTR}^{\prime}=\mathrm{Q} *\left\{\mathrm{BOD}_{\text {Inlet }}+4.3^{*}\left(\mathrm{NH}_{4}-\mathrm{N}_{\text {Inlet }}\right)\right\} /$ Total area

OTR' : $\mathrm{mg} \mathrm{O}_{2} \mathrm{~m}^{-2} \mathrm{~d}^{-1} ; \mathrm{Q}: \mathrm{m}^{3} \mathrm{~d}^{-1}$; total area: $\mathrm{m}^{2}$; inlet concentrations: $\mathrm{mg} \mathrm{L}^{-1}$.

The statistical analysis of the data was performed using the programme 'Analyse-it 2.22'. Spearman Rank Correlation analysis was used for analyzing the relationship between the water quality and environmental indicators, OTR and $\mathrm{OTR}^{\prime}$, k values, mass loading rates and mass removed rates. The level of significance of alpha=0.05 was accepted in all cases. 


\subsection{System efficiency for pollutant removal}

The efficiency of hybrid sub-surface CW was calculated in terms of purification and removal rates for all selected parameters of wastewater for each year from 2007 to 2010.

Purification rate was calculated using following formulae:

Purification rate $(\%)=\left\{\left(\mathrm{C}_{\mathrm{i}}-\mathrm{C}_{0}\right) / \mathrm{C}_{\mathrm{i}}\right\} * 100$

$\mathrm{C}_{\mathrm{i}}$ : Inlet concentration $\left(\mathrm{mg} \mathrm{L}^{-1}\right) ; \mathrm{C}_{0}$ : Outlet concentration $\left(\mathrm{mg} \mathrm{L}^{-1}\right)$.

Removal rate was calculated using following formulae:

Removal rate $(\%)=\left\{\left(L_{i}-L_{0}\right) / L_{i}\right\} * 100$

$\mathrm{L}_{\mathrm{i}}$ : Inlet load $\left(\mathrm{g} \mathrm{m}^{-2} \mathrm{~d}^{-1}\right) ; \mathrm{L}_{\mathrm{o}}$ : Outlet load $\left(\mathrm{g} \mathrm{m}^{-2} \mathrm{~d}^{-1}\right)$

Load was calculated using following formulae:

$\operatorname{Load}(\mathrm{L})=\mathrm{Q}{ }^{*} \mathrm{C} / \mathrm{A}$

Q: Flow rate $\left(\mathrm{m}^{3} \mathrm{~d}^{-1}\right)$; C: concentration $\left(\mathrm{mg} \mathrm{L}^{-1}\right)$; A: area $\left(\mathrm{m}^{2}\right)$.

\subsection{Results and Discussion}

\subsection{Meteorology}

The average precipitation in Embetsu was recorded as 1,053 $\mathrm{mm} \mathrm{y}^{-1}$. Daily average air temperature was $6.4{ }^{\circ} \mathrm{C}$ with extremes varying between $-7.9{ }^{\circ} \mathrm{C}$ as lowest at the end of January and $20.3{ }^{\circ} \mathrm{C}$ as highest in the beginning of August. Average of annual record of minimum and maximum temperature is $-22.8{ }^{\circ} \mathrm{C}$ and $30.6{ }^{\circ} \mathrm{C}$ for the period of 1978 to 2009 . The cold period represents about 4 months from December to March. Snow covers the terrain during this period.

\subsection{Composition of influent}


Influent was discharged from a milking parlor located in the premises of dairy farm. Approximately, 120 cows were milked in this milking parlor twice in a day throughout the study period. The influent was a mixture of wastewaters generated from various operations of milking parlor, such as floor washings, disinfectant and detergent washings, wastewater from equipments, spilled milk, cow dung and urine.

In 2007, from February to December, large quantity of rejected milk was also mixed with influent every day. Nearly all times, Influent was yellowish in color with strong odor.

Average influent volume was $4.9 \mathrm{~m}^{3} \mathrm{~d}^{-1}$ and ranged from 1.2 to $36.2 \mathrm{~m}^{3} \mathrm{~d}^{-1}$ during the study period. Higher volume was observed during snow melting seasons and heavy precipitation.

\section{3 $p H, E C, D O, O R P$}

$\mathrm{pH}$ of influent ranged between 4.7 to 8.1 during study period with an average of 6.6 showing nearly neutral nature. Average $\mathrm{pH}$ from influent to effluent was more or less similar in 2007 and 2008 however; it showed an increase of 0.4 and 0.3 unit in 2009 and 2010 respectively (Table 2). Daily mean influent temperature was $13.0{ }^{\circ} \mathrm{C}$ and fluctuated between 3.6 to $23.2{ }^{\circ} \mathrm{C}$. Lowest and highest temperature was recorded on $12^{\text {th }}$ March 2007 and $11^{\text {th }}$ August 2010 respectively. Average influent DO increased during treatment. Maximum DO increase was observed in 2007. Usually during initial periods of operation, filter material of CW beds occupy greater amount of atmospheric oxygen which results into increase in DO level of influent during course of treatment. EC 
showed a decrease during treatment. Average influent EC ranged between 1.0 to $1.5 \mathrm{mS} \mathrm{cm}^{-1}$ being maximum in 2007 and minimum in 2008 . Higher EC values in 2007 were due to addition of rejected milk in influent. Effluent EC was observed in a range of 0.7 to $0.9 \mathrm{mS} \mathrm{cm}^{-1}$. EC decrease rate fluctuated from 30 to $43 \%$ throughout the study period. Average influent ORP ranged between 283-264 mV from 2007 to 2010 and showed an increase in the effluent during each year. Maximum increase of $+68 \mathrm{mV}$ was observed in 2009.

\subsection{Concentrations and purification rates}

Hybrid CW system received high fluctuations in average yearly inlet concentrations for TSS (526.0 - 1,259 mg L $\left.{ }^{-1}\right)$, BOD $_{5}\left(1,080-2,114 \mathrm{mg} \mathrm{L}^{-1}\right)$, $\operatorname{COD}\left(1,962-7,085 \mathrm{mg} \mathrm{L}^{-1}\right), \mathrm{TN}\left(116.0-243.0 \mathrm{mg} \mathrm{L}^{-1}\right), \mathrm{NH}_{4}\left(54.0-90.0 \mathrm{mg} \mathrm{L}^{-1}\right)$, TC (1,022-2,215 $\left.\mathrm{mg} \mathrm{L}^{-1}\right)$ and TP (15.3-41.7 $\left.\mathrm{mg} \mathrm{L}^{-1}\right)$ during study period (Table 2). Average yearly purification rate fluctuation was observed as; TSS (96-99\%), COD (88-96\%), BOD (90-96\%), TN (74-91\%), TP (65-87\%) and TC (79-91\%). Average concentrations of all parameters were highest in the influent and effluent during 2007 compared to rest years. In 2007 a large quantity of rejected milk was also mixed with influent and thrown to hybrid CWs which resulted into high concentrations of water quality parameters of the influent during this period. In 2007, average influent concentrations of TSS, TP, $\mathrm{PO}_{4}-\mathrm{P}$ and TC were observed nearly 3 times higher compared to 2008. Average effluent concentrations showed similar trend to influent and were highest during 2007 for all parameters. Average concentrations of TSS, TP, $\mathrm{PO}_{4}-\mathrm{P}, \mathrm{TN}, \mathrm{NH}_{4}-\mathrm{N}$ and total coliform in the effluent of all years were below the discharge limit value of: 
$150 \mathrm{mg} \mathrm{L}^{-1}$ for TSS; $8 \mathrm{mg} \mathrm{L}^{-1}$ for TP and $\mathrm{PO}_{4}-\mathrm{P}, 60 \mathrm{mg} \mathrm{L}^{-1}$ for $\mathrm{TN}$ and $\mathrm{NH}_{4}-\mathrm{N}$ and 3000 no. $\mathrm{ml}^{-1}$ for total coliform. However, average $\mathrm{BOD}_{5}$ and $\mathrm{COD}_{\mathrm{Cr}}$ concentrations could not meet the discharge limit value of $120 \mathrm{mg} \mathrm{L}^{-1}$ during 2007 and 2008. Figure 2 presents average purification rates of hybrid system for TSS, $\mathrm{COD}_{\mathrm{Cr}}, \mathrm{BOD}_{5}, \mathrm{TN}, \mathrm{NH}_{4}-\mathrm{N}, \mathrm{TP}, \mathrm{TC}$ and total coliform. In 2008, average concentrations of TSS, COD $\mathrm{Cr}$, TN, TP and TC in the influent dropped by 67,72 , 52,63 and $62 \%$ respectively with respect to their concentrations in 2007 . This significant concentration drop resulted into decrease in average purification rates of TSS, $\mathrm{COD}_{\mathrm{Cr}}, \mathrm{TN}, \mathrm{TP}$ and TC by 1.9, 3.2, 8.3, 22.2 and $9.4 \%$ respectively in 2008 compared to 2007 (Fig.2). TSS and COD Cr $_{\text {purification }}$ rates were slightly affected by large variations in influent concentrations between two consecutive years. The major source of TSS was excreta of cows which mixed with the influent during floor washing operations at milking parlor. A positive correlation between TSS and $\mathrm{COD}_{\mathrm{Cr}}$ (Spearman R value; 0.85, $p<0.0001)$ shows that COD $_{\mathrm{Cr}}$ was mainly in the form of particulate COD and derived from TSS. TSS is purified by sedimentation and filtration processes which are slightly affected by variations in inlet concentrations.

TN and TC showed moderate decrease in purification rates from 2007 to 2008. $\mathrm{TN}$ in the wastewater is sum of organic and inorganic $\left(\mathrm{NH}_{4}-\mathrm{N}, \mathrm{NO}_{2}-\mathrm{N}\right.$ and $\mathrm{NO}_{3}-$ $\mathrm{N})$ nitrogen. In 2007, average organic and inorganic $\mathrm{N}$ content in influent accounted for 62.6 and $37.4 \%$ respectively whereas in 2008 TN comprised of $53.4 \%$ organic and $46.6 \%$ inorganic $\mathrm{N}$. The organic $\mathrm{N}$ was mainly in the form of excreta which settled on the surfaces of beds. While $\mathrm{NH}_{4}-\mathrm{N}$ dominated in 
inorganic nitrogen. A sharp decrease of $22.2 \%$ was observed in the purification rate of TP from 2007 to 2008 (Fig.2). TP purification takes place by adsorption and precipitation of dissolved $P$ in the filter material of the beds of CWs. When TP concentrations in influent dropped sharply the apparent release of accumulated phosphorus from the binding sites of filter media might resulted into a sharp decrease in the TP purification rate. Arias et al., (2003) also found similar results in his study. Average influent $\mathrm{BOD}_{5}$ and $\mathrm{NH}_{4}-\mathrm{N}$ concentrations in 2008 decreased by 35.7 and $40 \%$ respectively. However $\mathrm{BOD}_{5}$ and $\mathrm{NH}_{4}-\mathrm{N}$ purification rates increased by 1.3 and $3 \%$ in 2008 compared to 2007 . Generally $\mathrm{BOD}_{5}$ and $\mathrm{NH}_{4}-\mathrm{N}$ purification rates decrease by increasing concentrations. In 2009, average TSS, $\mathrm{COD}_{\mathrm{Cr}}, \mathrm{TN}, \mathrm{TP}, \mathrm{NH}_{4}-\mathrm{N}$ and $\mathrm{TC}$ concentrations in the influent were increased by $27,61,28,45,59$ and $23 \%$ respectively in contrast to 2008. Moreover, average purification rates of TSS, COD $\mathrm{Cr}, \mathrm{TN}, \mathrm{TP}, \mathrm{NH}_{4}-\mathrm{N}$ and TC in 2009 increased by 2.8, 4.4, 2.0, 12.8, 10.4 and $1.6 \%$ respectively compared to 2007. Generally high influent concentrations correspond with high purification rates in CWs, reflecting their high buffer capacity (Ye and Li, 2009). In our system, although inlet concentrations of all parameters i.e. TSS, BOD, COD, TN, $\mathrm{NH}_{4}-\mathrm{N}, \mathrm{TC}, \mathrm{TP}$ showed high fluctuations but purification rates for these parameters were not fluctuated to that extent. Specifically, BOD purification rate, which fluctuated only $6 \%$ in spite of huge fluctuations in inlet BOD concentrations $\left(1,080-2,114 \mathrm{mg} \mathrm{L}^{-1}\right)$. This can be explained by high decomposition rate of organic matter (BOD) during the period when system received high inlet concentrations. This confirms that Embetsu hybrid CWs 
posses a good buffer capacity. Kern (2003) also reported similar results during treatment of dairy wastewater using $\mathrm{CWs}$. Average $\mathrm{BOD}_{5}$ concentrations in influent although increased by $20 \%$ in 2009 than 2008 however purification rate remained unaffected. In 2010 compared to 2009, average concentrations of all parameters except $\mathrm{NH}_{4}-\mathrm{N}$ showed an increase in the influent, likewise purification rates of all parameters resulted an increase during this period.

Total coliform concentration in influent showed a great fluctuation from 2007 to 2010, being highest in 2010 and lowest in 2009. However, purification rates were always $>90 \%$ reaching as high as $99.5 \%$ in 2008 .

Among all parameters, average yearly purification rates of $\mathrm{TN}, \mathrm{NH}_{4}$ and $\mathrm{TP}$ showed high fluctuations as a result of inlet load fluctuations. Our results are comparable with Kato et al., (2013) who operated 3 hybrid CWs at different inlet loading rates (COD: $2,400-5,000 \mathrm{mg} \mathrm{L}^{-1}$ ) for dairy waste water treatment and observed a fluctuation of $39-90 \%$ for TN, $36-82 \%$ for $\mathrm{NH}_{4}-\mathrm{N}$ and $70-93 \%$ for TP.

\subsection{Loads and Removal rates}

Load and removal rates are more accurate way to present the treatment efficiencies of CWs because concentration and purification rates might alter due to precipitation, evaporation and evapo-transpiration processes. Similar to concentrations, high fluctuations in average yearly inlet loads were observed for TSS $\left(2.7-9.0 \mathrm{~g} \mathrm{~m}^{-2} \mathrm{~d}^{-1}\right)$, BOD $_{5}\left(8.4-14.4 \mathrm{~g} \mathrm{~m}^{-2} \mathrm{~d}^{-1}\right), \operatorname{COD}\left(14.5-50.0 \mathrm{~g} \mathrm{~m}^{-2}\right.$ $\left.\mathrm{d}^{-1}\right), \mathrm{TN}\left(0.8-1.6 \mathrm{~g} \mathrm{~m}^{-2} \mathrm{~d}^{-1}\right), \mathrm{NH}_{4}\left(0.40-0.64 \mathrm{~g} \mathrm{~m}^{-2} \mathrm{~d}^{-1}\right), \mathrm{TC}\left(6.0-15.1 \mathrm{~g} \mathrm{~m}^{-2} \mathrm{~d}^{-1}\right)$ and TP $\left(0.11-0.28 \mathrm{~g} \mathrm{~m}^{-2} \mathrm{~d}^{-1}\right)$ throughout the study period (Table 3). Average yearly removal rate fluctuation was observed as; TSS (96-99\%), COD (88-94\%), 


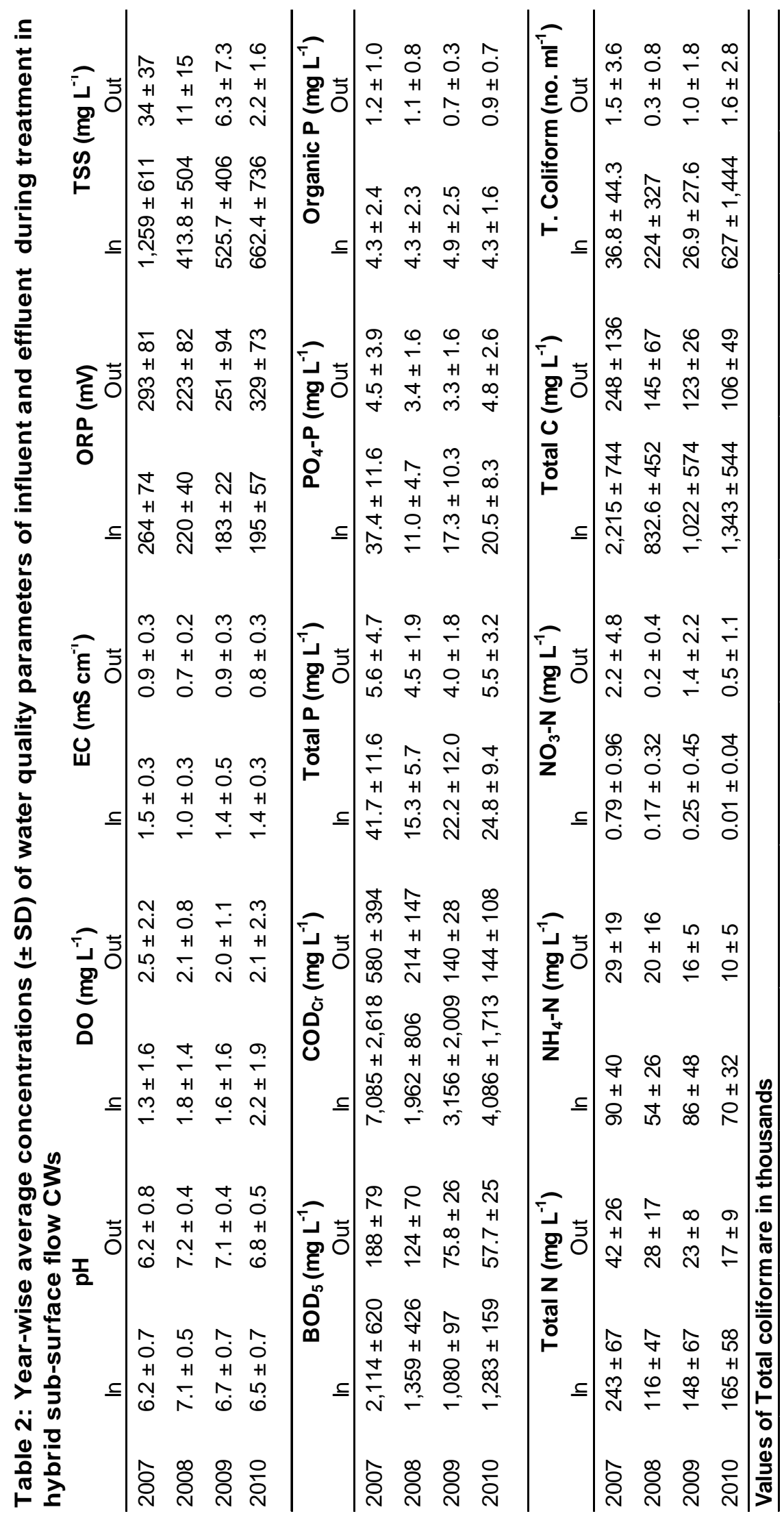


BOD (86-94\%), TN (73-86\%), TP (65-86\%) and TC (80-89\%). Average loads of TSS, BOD $, \mathrm{COD}_{\mathrm{Cr}}, \mathrm{TN}, \mathrm{TP}, \mathrm{PO}_{4}-\mathrm{P}$ and TC in the influent were highest in 2007 except $\mathrm{NH}_{4}-\mathrm{N}$ load which was highest in 2009. Average TSS and COD $\mathrm{Cr}$ loads decreased by nearly $70 \%$ in influent in 2008 compared to 2007 . However removal rates of TSS and $\mathrm{COD}_{\mathrm{Cr}}$ were almost unaffected with a slight decrease. Furthermore, average TP and $\mathrm{PO}_{4}-\mathrm{P}$ load in influent was also dropped by 61 and $68 \%$ along with a sharp decline of 21 and $18 \%$ in removal rates during 2008 (Fig. 3). As stated in the previous section, release of accumulated phosphorus might be the most probable reason for this decrease in removal rate. In contrast, $\mathrm{BOD}_{5}$ load although decreased by $30 \%$ in 2008 but showed an increase in removal rate by $4.4 \%$. BOD removal mechanism is associated with microbial degradation of organic matter in presence of sufficient oxygen required by microorganisms. Oxygen transfer rate remains more or less

Table 3: Year-wise average $( \pm S D$ ) load of water quality parameters in influent and effluent during treatment in hybrid sub-surface flow CWs

\begin{tabular}{|c|c|c|c|c|c|c|c|c|}
\hline & \multicolumn{2}{|c|}{ TSS } & \multicolumn{2}{|c|}{$\mathrm{BOD}_{5}$} & \multicolumn{2}{|c|}{$\operatorname{COD}_{\mathrm{Cr}}$} & \multicolumn{2}{|c|}{ TN } \\
\hline & In & Out & In & Out & In & Out & In & Out \\
\hline 2007 & $9.0 \pm 4.5$ & $0.28 \pm 0.3$ & $14.4 \pm 4.1$ & $1.9 \pm 0.7$ & $50.0 \pm 4.5$ & $4.9 \pm 3.2$ & $1.6 \pm 0.6$ & $0.36 \pm 0.2$ \\
\hline 2008 & $2.7 \pm 1.8$ & $0.08 \pm 0.1$ & $10.0 \pm 4.5$ & $1.0 \pm 0.6$ & $14.5 \pm 5.7$ & $1.7 \pm 1.0$ & $0.8 \pm 0.3$ & $0.22 \pm 0.1$ \\
\hline 2009 & $4.3 \pm 2.2$ & $0.05 \pm 0.0$ & $8.4 \pm 2.8$ & $0.8 \pm 0.3$ & $23.4 \pm 13.1$ & $1.4 \pm 0.6$ & $1.1 \pm 0.4$ & $0.23 \pm 0.1$ \\
\hline \multirow[t]{3}{*}{2010} & $5.5 \pm 3.8$ & $0.03 \pm 0.0$ & $9.2 \pm 2.6$ & $0.5 \pm 0.2$ & $31.9 \pm 9.9$ & $1.6 \pm 0.7$ & $1.2 \pm 0.5$ & $0.15 \pm 0.1$ \\
\hline & \multicolumn{2}{|c|}{$\mathrm{NH}_{4}-\mathrm{N}$} & \multicolumn{2}{|c|}{ Total P } & \multicolumn{2}{|c|}{$\mathrm{PO}_{4}-\mathrm{P}$} & \multicolumn{2}{|c|}{ Total C } \\
\hline & In & Out & In & Out & In & Out & In & Out \\
\hline 2007 & $0.64 \pm 0.2$ & $0.24 \pm 0.1$ & $0.28 \pm 0.1$ & $0.04 \pm 0.0$ & $0.25 \pm 0.1$ & $0.03 \pm 0.0$ & $15.1 \pm 4.1$ & $2.2 \pm 1.1$ \\
\hline 2008 & $0.40 \pm 0.1$ & $0.16 \pm 0.1$ & $0.11 \pm 0.1$ & $0.04 \pm 0.0$ & $0.08 \pm 0.0$ & $0.03 \pm 0.0$ & $6.02 \pm 2.2$ & $1.1 \pm 0.5$ \\
\hline 2009 & $0.66 \pm 0.3$ & $0.15 \pm 0.1$ & $0.17 \pm 0.1$ & $0.04 \pm 0.0$ & $0.13 \pm 0.1$ & $0.03 \pm 0.0$ & $7.65 \pm 3.7$ & $1.1 \pm 0.4$ \\
\hline 2010 & $0.53 \pm 0.2$ & $0.10 \pm 0.0$ & $0.20 \pm 0.1$ & $0.06 \pm 0.0$ & $0.16 \pm 0.0$ & $0.05 \pm 0.0$ & $10.3 \pm 3.4$ & $1.1 \pm 0.6$ \\
\hline
\end{tabular}

Unit for all parameters is $\mathrm{g} \mathrm{m}^{2} \mathrm{~d}^{-1}$ 

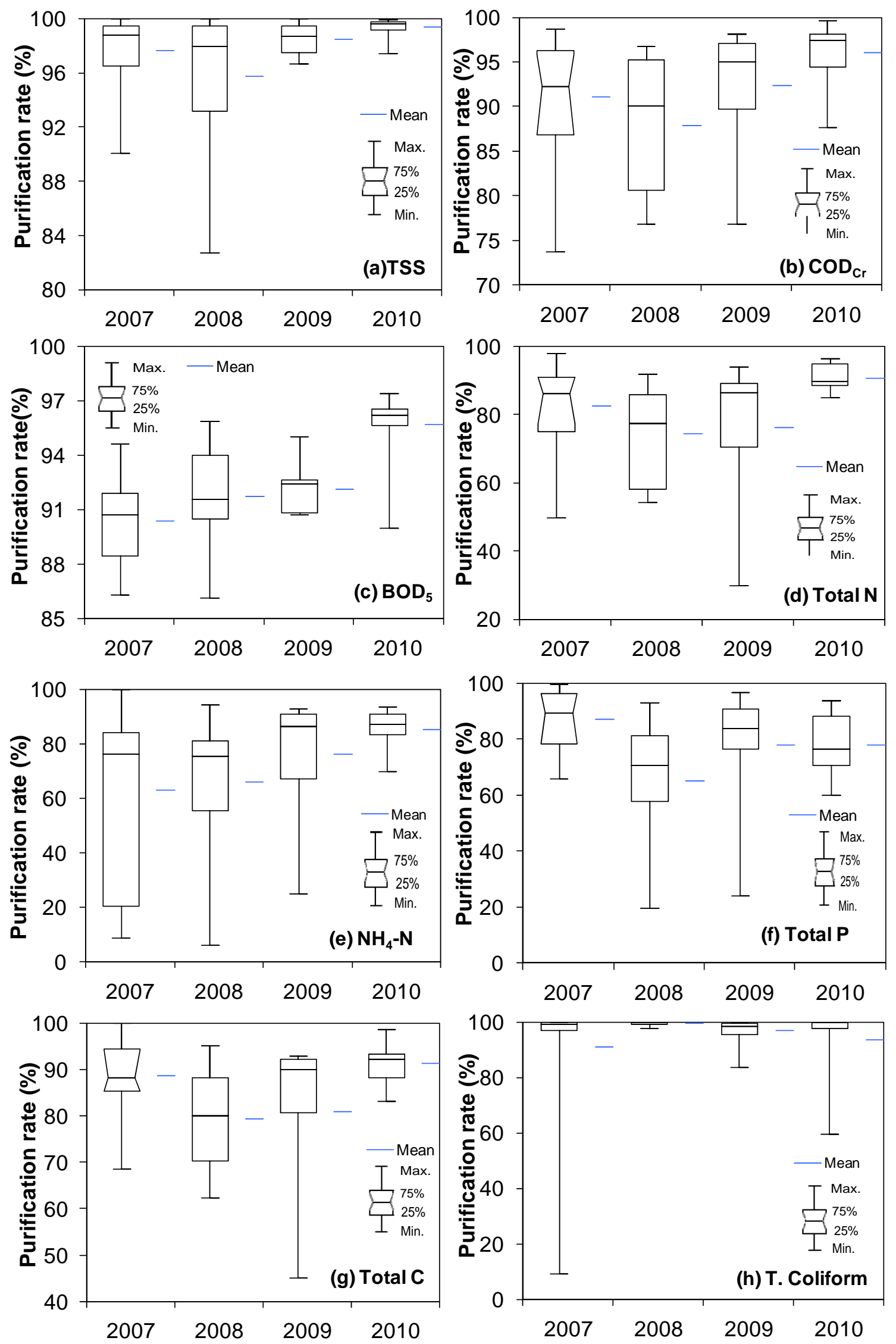

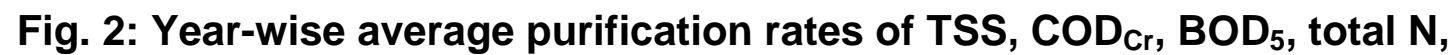
$\mathrm{NH}_{4}-\mathrm{N}$, total $\mathrm{P}$, total $\mathrm{C}$ and total coliform during treatment of milking parlor waste water in hybrid CWs 
constant in a hybrid CW system during treatment, if clogging and/or over flooding does not happens on the bed surface. An increase in inlet BOD load decreases removal rate due to higher demand of oxygen for biological degradation. This was the reason for lower BOD removal rate in 2007 compared to 2008.TN, $\mathrm{NH}_{4}-\mathrm{N}$ and TC loads dropped by $50,37.5$ and $60 \%$ respectively in 2008 and further increased by 37.5, 65 and 27\% respectively in 2009 compared to their preceding year's average load. However average removal rates of $\mathrm{TN}, \mathrm{NH}_{4}-\mathrm{N}$ and $\mathrm{TC}$ showed a decrease of $6.1,3.4$ and $5.4 \%$ respectively in 2008 and an increase of $4.5,8.3$ and 3.0\% respectively in 2009 compared to the preceding year of 2007 and 2008.

Hybrid CWs are known for higher TN removal mainly due to nitrificationdenitrification processes (Brix and Arias, 2005). Therefore, recycling of wastewater was carried out from outlet to inlet tank of VF(b) from 2008 to 2010 during growing season (April-October). We observed higher TN removal rates during recycling period compared to non-growing season (November-March) from 2008 to 2010. Several other researchers such as Brix and Arias, 2005; Hamouri et al., 2012 and Kato et al., 2013 also observed an increase in TN removal rate due to recycling of wastewater in hybrid CWs.

In 2009 and 2010, Average influent loads of TSS, COD ${ }_{C r}, T N, T P, P_{4}-P$ and TC resulted an increase from the preceding year such as; TSS increased by $59 \%$ in 2009 and $28 \%$ in 2010. Similarly, COD $\mathrm{Cr}$, TN, TP, $\mathrm{PO}_{4}-\mathrm{P}$ and TC loads increased by $61,36,55,63$ and $27 \%$ respectively in 2009 and 36, 9, 18, 23 and 
$35 \%$ respectively in 2010 . Moreover removal rates resulted an increase from none to $8.5 \%$ in 2009 and $2-9 \%$ in 2010 for these parameters.

\subsection{OTR and OTR'}

OTR' reflects that total amount of $\mathrm{O}_{2}$ required in a CWs for full degradation of organic matter as well as nitrification of $\mathrm{NH}_{4}-\mathrm{N}$ from that wastewater whereas OTR is the actual $\mathrm{O}_{2}$ utilized by a CWs for organic matter degradation and nitrification processes during course of wastewater treatment. OTR value fluctuates if a CWs receives fluctuations in inlet load and HLR etc. Hybrid CWs at Embetsu was operated under high inlet load fluctuations, therefore it is important to investigate the effects of inlet load fluctuations on OTR value of each bed and total system.

OTR values for VF(a), VF(b), HF bed and total system were found as $21.7,19.3$, 4.8 and $12.3 \mathrm{~g} \mathrm{O}_{2} \mathrm{~m}^{-2} \mathrm{~d}^{-1}$ respectively. OTR showed a great degree of fluctuation i.e. 5.1 to $68.6 \mathrm{~g} \mathrm{O}_{2} \mathrm{~m}^{-2} \mathrm{~d}^{-1}$ in $\operatorname{VF}(\mathrm{a})$ \& $\operatorname{VF}(\mathrm{b})$ beds and 1.5 to $17.9 \mathrm{O}_{2} \mathrm{~m}^{-2} \mathrm{~d}^{-1}$ in HF bed. In a recent study, Kato et al., (2013) reported OTR values of 16-32 g $\mathrm{O}_{2} \mathrm{~m}^{-2} \mathrm{~d}^{-1}$ from 3 different hybrid CWs operated for dairy waste water treatment. $\mathrm{OTR}^{\prime}$ is always higher than OTR because full degradation of organic matter and nitrification of ammonium nitrogen are difficult to achieve at real scale. Table 4 represents correlation between and within OTR and OTR' values of VF(a), VF(b), $\mathrm{HF}$ beds and total system. OTR' of total system was positively correlated with OTR and OTR' values of VFa, VFb, HF bed and total system (Spearman R values varied from 0.54 to 1.00$)$. Likewise, OTR' value of each bed was significantly positively correlated with the OTR value of the same bed. 

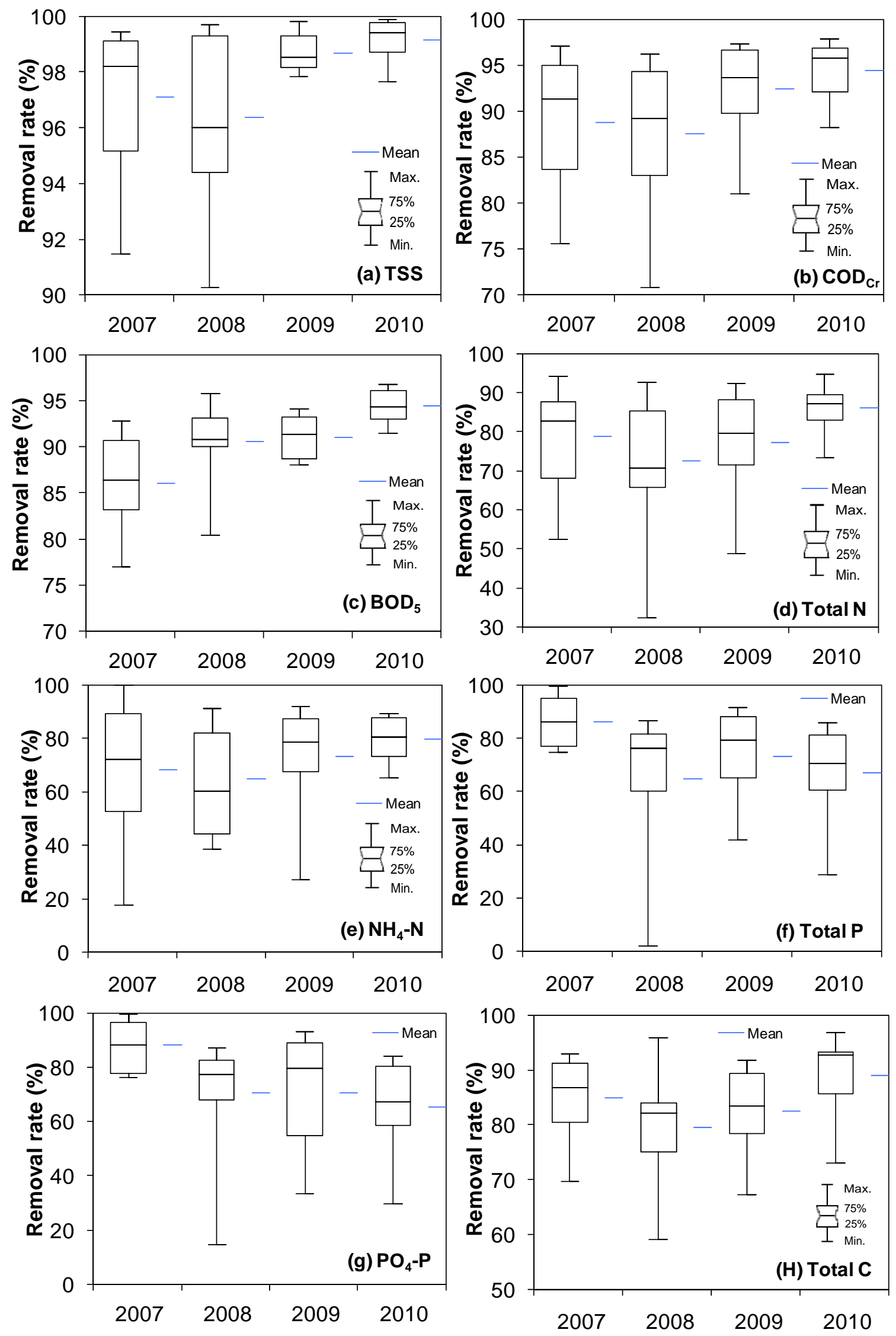

Fig. 3: Year-wise average removal rates of TSS, $\operatorname{COD}_{\mathrm{Cr}}, \mathrm{BOD}_{5}$, total $\mathrm{N}$, $\mathrm{NH}_{4}-\mathrm{N}$, total $\mathrm{P}, \mathrm{PO}_{4}-\mathrm{P}$ and total $\mathrm{C}$ during treatment of milking parlor waste water in hybrid CWs 
(Spearman R values: 0.71 for $\operatorname{VF}(a), 0.94$ for both $\operatorname{VF}(b)$ and HF beds).OTR values of influent were found positively correlated with EC, TSS, COD $\mathrm{Cr}$, TP, $\mathrm{PO}_{4}-\mathrm{P}, \mathrm{TN}, \mathrm{TC}, \mathrm{BOD}_{5}$ and $\mathrm{NH}_{4}-\mathrm{N}$ (Spearman $\mathrm{R}$ values varied from 0.45 to 0.89 with level of significance $<0.05$ for $\mathrm{BOD}_{5}, \mathrm{NH}_{4}-\mathrm{N}$ and $<0.0001$ for others).

\subsection{Correlation between environmental parameters and water indicators}

Spearman rank correlation was used to assess the correlation between environmental parameter i.e. air temperature and water quality parameters at inflow and outflow (Table 5). As expected the EC was positively correlated with $\mathrm{COD}_{\mathrm{Cr}}, \mathrm{TP}, \mathrm{TN}, \mathrm{NH}_{4}-\mathrm{N}$ and Total $\mathrm{C}$ concentrations in the influent (Spearman $\mathrm{R}$ value varied from 0.62 to $0.86, p<0.0001)$. Influent water temperature and air temperatures were negatively correlated with influent $\mathrm{pH}$ and $\mathrm{DO}$ (Spearman $\mathrm{R}$ value varied from -0.57 to $-0.64, p<0.0001)$. However, water temperature showed a positive correlation with influent EC ( $R$ value, $0.37, p<0.05$ ).

Table 4: Spearman Rank Correlation $\left(R^{2}\right)$ between OTR $\left(\mathrm{g} \mathrm{m}^{-2} \mathrm{~d}^{-1}\right)$ and OTR $(\mathrm{g}$ $\mathbf{m}^{-2} \mathbf{d}^{-1}$ ) values of $\mathrm{VF}(\mathrm{a}), \mathrm{VF}(\mathrm{b}), \mathrm{HF}$ bed and total system in Embetsu

\begin{tabular}{|c|c|c|c|c|c|c|c|c|}
\hline & $\begin{array}{c}\text { OTR } \\
\text { (VFA) }\end{array}$ & $\begin{array}{c}\text { OTR } \\
\text { (VFB) }\end{array}$ & $\begin{array}{l}\text { OTR } \\
\text { (HF) }\end{array}$ & $\begin{array}{c}\text { OTR } \\
\text { (Total) }\end{array}$ & $\begin{array}{l}\text { OTR }^{\prime} \\
\text { (VFA) }\end{array}$ & $\begin{array}{l}\mathrm{OTR}^{\prime} \\
\text { (VFB) }\end{array}$ & $\begin{array}{l}\text { OTR }^{\prime} \\
\text { (HF) }\end{array}$ & $\begin{array}{c}\text { OTR }^{\prime} \\
\text { (Total) }\end{array}$ \\
\hline OTR (VFa) & 1.00 & & & & & & & \\
\hline OTR (VFb) & 0.33 & 1.00 & & & & & & \\
\hline OTR (HF) & 0.01 & $0.62^{*}$ & 1.00 & & & & & \\
\hline OTR (Total) & $0.83^{*}$ & $0.67^{*}$ & 0.41 & 1.00 & & & & \\
\hline $\mathrm{OTR}^{\prime}(\mathrm{VFa})$ & $0.71^{*}$ & $0.72^{*}$ & 0.54 & $0.96^{*}$ & 1.00 & & & \\
\hline OTR'(VFb) & 0.21 & $0.94^{*}$ & $0.76^{*}$ & $0.63^{*}$ & $0.74^{*}$ & 1.00 & & \\
\hline $\mathrm{OTR}^{\prime}(\mathrm{HF})$ & 0.01 & $0.64^{*}$ & $0.94^{*}$ & 0.44 & $0.57^{\star}$ & $0.78^{*}$ & 1.00 & \\
\hline OTR'(Total) & $0.71^{*}$ & $0.72^{*}$ & 0.54 & $0.96^{*}$ & $1.00^{*}$ & $0.74^{*}$ & $0.57^{*}$ & 1.00 \\
\hline
\end{tabular}

Significant values: (bold) $p<0.05$, (bold with asterisk) $p<0.0001$ 
Furthermore, influent $\mathrm{pH}$ was negatively correlated with the concentrations of $\mathrm{COD}_{\mathrm{cr}}, \mathrm{TP}, \mathrm{TN}$ and Total $\mathrm{C}(\mathrm{R}$ value varied from -0.57 to $-0.65, \mathrm{p}<.0 .0001)$ and EC ( $R$ value $-0.39, p<0.05)$. Apart from insignificant relationship between $\mathrm{NH}_{4}-\mathrm{N}$ and $\mathrm{BOD}_{5}$ concentrations, $\mathrm{COD}_{\mathrm{Cr}}, \mathrm{BOD}_{5}, \mathrm{TP}, \mathrm{TN}$ and $\mathrm{NH}_{4}-\mathrm{N}$ concentrations in the influent confirmed a significant positive correlation among each other (Spearman $\mathrm{R}$ value varied from 0.49 to 0.99 ). On the other hand, effluent TP concentration was significantly positively correlated with air and influent temperatures as well as influent flow. $(R$ values varied from 0.31 to 0.39 , $p<0.05)$. Higher influent flow especially during snow melting period might have carried precipitated phosphorus from the bed. During summer seasons higher air and water temperatures might have increased the evaporation and evapotranspiration rates at beds resulting higher TP concentrations in the effluent. Öövel et al., (2007) found the similar results in his study during treatment of schoolhouse wastewater in a hybrid constructed wetland system at Estonia. Influent DO was negatively correlated with effluent water temperature ( $R$ value 0.67, $\mathrm{p}<0.0001)$. Influent $\mathrm{COD}_{\mathrm{Cr}}, \mathrm{BOD}_{5}$ and $\mathrm{TC}$ concentrations were negatively correlated with $\mathrm{pH}$ ( $\mathrm{R}$ value -0.36 and $-0.37, \mathrm{p}<0.05)$. This is due to the fact that when during biological degradations of the organic matter (COD, BOD and total carbon), acids are released as an intermediate products by acidophilic microorganisms which decrease the $\mathrm{pH}$ of waste water. Influent and effluent $\mathrm{COD}_{\mathrm{Cr}}$, and TC concentrations showed a positive significant correlation with each other ( Spearman R value varied from 0.40 to $0.43, p<0.05$ ). Similar to influent DO, effluent DO concentration was negatively correlated with effluent 
temperature and air temperature. ( $R$ values -0.43 and $-0.47, p<0.05$ ). EC is directly related to dissolved ions present in the water and this resulted a positive correlation of EC with TP, TN, TC at $\mathrm{p}<0.0001$ and $\mathrm{NH}_{4}-\mathrm{N}$ at $\mathrm{p}<0.05$ in the effluent. In the effluent, $\mathrm{COD}_{\mathrm{Cr}}$ also showed a positive correlation with $\mathrm{BOD}_{5}, \mathrm{TN}$, $\mathrm{NH}_{4}-\mathrm{N}$, TC concentrations at $\mathrm{p}<0.0001$ (Spearman $\mathrm{R}$ value varied from 0.61 t0 0.81) and TP concentration at $p<0.05$ (Spearman $R$ value 0.30).TN concentration in the effluent too was positively correlated with $\mathrm{NH}_{4}-\mathrm{N}$ and TC concentration ( $R$ value 0.91 and $0.74, p<0.0001$ ).

\subsection{Application of $k-C^{*}$ model}

The average and standard deviation values of the area-based first-order rateconstant $\mathrm{k}$ for $\mathrm{BOD}_{5}, \mathrm{TN}, \mathrm{NH}_{4}-\mathrm{N}$ and TP of the whole hybrid $\mathrm{CWs}$ throughout the study period were $7.0 \pm 1.8,7.4 \pm 3.3,5.6 \pm 4.1$ and $4.9 \pm 2.0 \mathrm{~m} \mathrm{yr}^{-1}$ respectively (Table 6). Average $k$ value of $\mathrm{BOD}_{5}$ in $\operatorname{VF}(\mathrm{a}), \mathrm{VF}(\mathrm{b})$ and $\mathrm{HF}$ bed was observed as $6.5 \pm 3.74,10.6 \pm 4.69$ and $6.4 \pm 3.1 \mathrm{~m} \mathrm{yr}^{-1}$ respectively The first-order rate-constant value $(k)$ of $\mathrm{BOD}_{5}$ was highest in $\mathrm{VF}(\mathrm{b})$ bed followed by HF and VF(a) bed. The bed area, filter material, and HRTs of both VF beds were same but inlet $\mathrm{BOD}_{5}$ load in $\mathrm{VF}(\mathrm{a})$ bed was as high as $45.0 \mathrm{~g} \mathrm{~m}^{-2} \mathrm{~d}^{-1}$ compared to $26 \mathrm{~g} \mathrm{~m}^{-2} \mathrm{~d}^{-1}$ in $\mathrm{VF}(\mathrm{b})$ bed. This resulted a more oxygen demand in VF(a) bed for decomposition of the biodegradable organic matter. However OTR values of both VF beds are nearly similar, This indicate more anaerobic conditions on $\operatorname{VF}(\mathrm{a})$ bed compared to $\operatorname{VF}(\mathrm{b})$ bed. On the other hand, average $\mathrm{k}$ values of TP in $\operatorname{VF}(a), \operatorname{VF}(b)$ and $H F$ bed were observed as $5.4 \pm 2.4,7.5 \pm 4.8$ and $7.6 \pm 5.8 \mathrm{~m} \mathrm{yr}^{-1}$ respectively. High $\mathrm{k}$ values in $\mathrm{VF}(\mathrm{b})$ than $\mathrm{VF}(\mathrm{a})$ beds were 


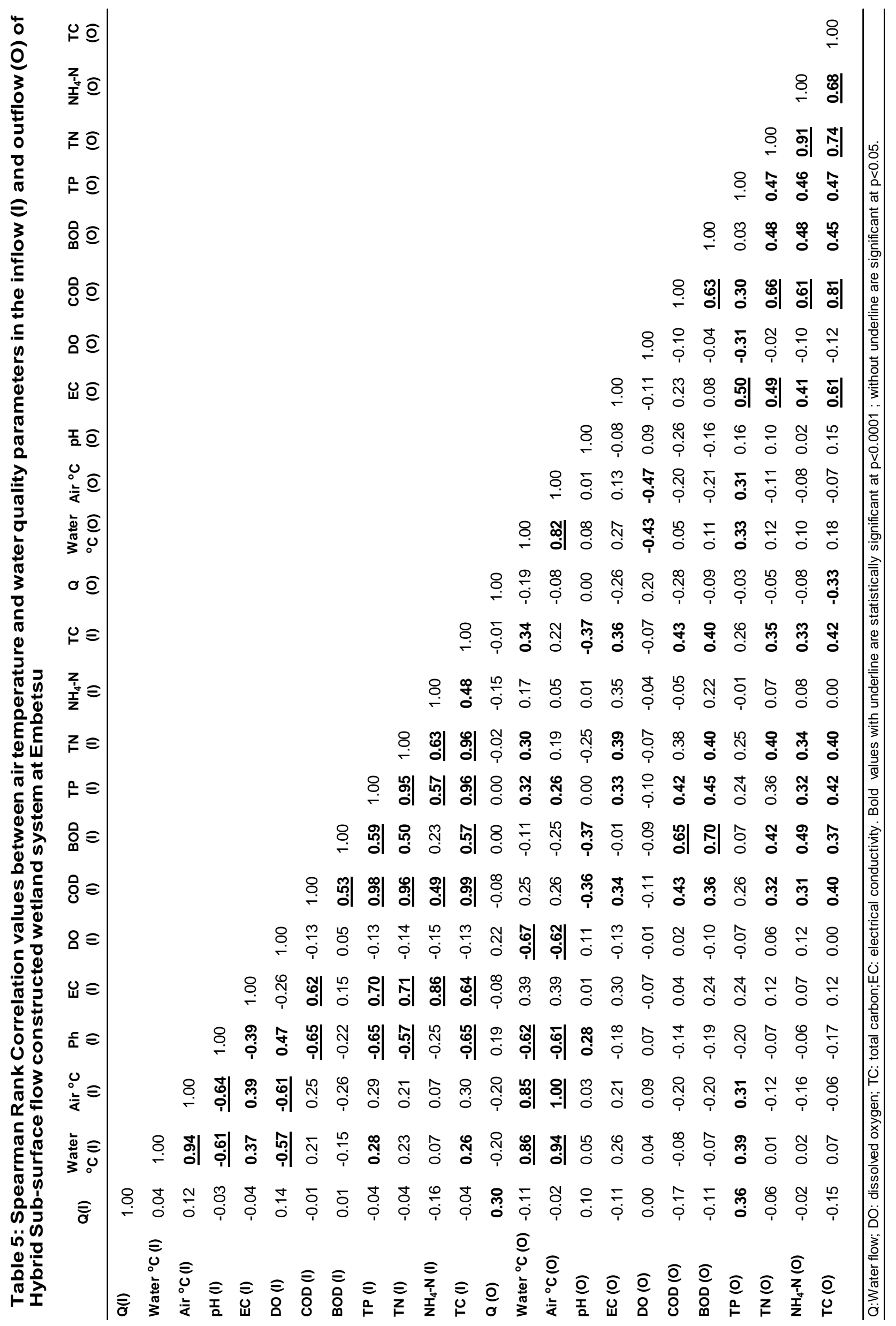


due to recycling of wastewater at $V F(b)$ bed during growing seasons. High $k$ value for HF bed was due to larger bed size and longer HRT in HF bed. Average $k_{20}$ values of $T N$ in $\operatorname{VF}(a), \operatorname{VF}(b)$ and $H F$ bed were $12.0 \pm 9.0,10.3 \pm$ 7.1 and $6.9 \pm 8.0$ respectively. Similarly average $k_{20}$ values for $\mathrm{NH}_{4}-\mathrm{N}$ in $\mathrm{VF}(\mathrm{a})$, $\mathrm{VF}(\mathrm{b})$ and HF beds were observed as $10.4 \pm 6.8,9.1 \pm 7.2$ and $8.6 \pm 10.8$ respectively. $\mathrm{k}$ values of $\mathrm{TN}$ and $\mathrm{NH}_{4}-\mathrm{N}$ for $\mathrm{VF}$ beds were higher than $\mathrm{HF}$ bed due to high nitrification rate at these beds as a result of more aerobic conditions at bed surfaces and denitrification of nitrified effluent at $\mathrm{VF}(\mathrm{b})$ inlet by recycling mechanism which were started in $\operatorname{VF}(b)$ bed in 2008. This in total resulted higher removal of $\mathrm{TN}$ and $\mathrm{NH}_{4}-\mathrm{N}$ loads in $\mathrm{VF}$ beds.

Average $\mathrm{k}$ values for total $\mathrm{N}$ and $\mathrm{NH}_{4}-\mathrm{N}$ were nearly similar in both $\mathrm{VF}$ beds but $\mathrm{k}$ values of $\mathrm{BOD}_{5}$ and total $\mathrm{P}$ showed a difference in both of these beds. $\mathrm{k}$ values of HF bed were lower than the $k$ values of $V F(a)$ and $V F(b)$ beds for $\mathrm{BOD}_{5}, \mathrm{TN}$ and $\mathrm{NH}_{4}-\mathrm{N}$. However $\mathrm{k}$ value of TP was almost similar in HF and VFB bed. Table 6 presents the Spearman Rank Correlation $\left(R^{2}\right)$ values among loading rate, removed load and area based first-order rate-constant $(k)$ value of $\mathrm{BOD}_{5}, \mathrm{TN}, \mathrm{NH}_{4}-\mathrm{N}$ and TP for entire hybrid CWs. A strong positive correlation was observed between loading rates of $\mathrm{BOD}_{5}, \mathrm{TN}, \mathrm{NH}_{4}-\mathrm{N}$ and TP and their corresponding removed loads (Spearman $\mathrm{R}$ value varied from 0.84 to 0.99 , $p<0.0001) . k$ value of Total $P$ was positively correlated with the loading rates of TN, $\mathrm{NH}_{4}-\mathrm{N}(\mathrm{R}$ value 0.48 and $0.53, \mathrm{p}<0.05)$ and $T P(\mathrm{R}$ value $0.57, \mathrm{p}<0.0001) . \mathrm{k}$ values of $\mathrm{TN}, \mathrm{NH}_{4}-\mathrm{N}$ and TP were significantly correlated with their respective removed loads ( $\mathrm{R}$ values 0.38 for $\mathrm{TN}, \mathrm{p}<0.05 ; 0.70$ and 0.73 for $\mathrm{NH}_{4}-\mathrm{N}$ and TP, 
$\mathrm{p}<0.0001)$. $\mathrm{k}$ values of $\mathrm{TN}, \mathrm{NH}_{4}-\mathrm{N}$, and TP were also significantly correlated among each other. ( $R$ for varied from 0.49 to 0.83 ). Significant correlation of $k$ values with mass loading and removal rates allow us to assume that the k- ${ }^{*}$ model describes the removal rates adequately and it can be used for the evaluation of the performance of constructed wetland systems like hybrid system of Embetsu.

\subsection{Conclusion}

Hybrid CW system received high fluctuations in influent load for all parameters from 2007 to 2010. Average influent TSS, COD, TP and TC load showed maximum fluctuation followed by $\mathrm{BOD}, \mathrm{TN}$ and $\mathrm{NH}_{4}-\mathrm{N}$ loads. However, besides such high fluctuations, purification and removal rates of hybrid CWs

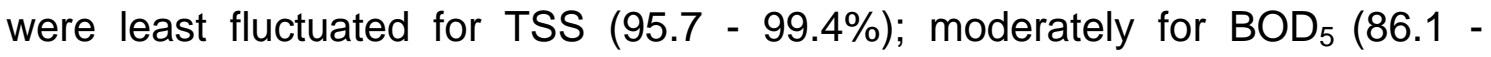
95.7\%), COD (87.5 - 96.1\%) and TC (79.5 - 91.3\%); highly for TN (72.6 90.6\%), $\mathrm{NH}_{4}-\mathrm{N}(62.9-85.3 \%)$ and TP (64.8 - 87.2\%). TSS is removed by physical processes such as sedimentation and filtration. This ensures that physical processes of CWs are highly tolerant to load fluctuations in a CW system compared to biological and chemical processes. Although COD load fluctuation was higher than BOD load but purification and removal rate fluctuation of both parameters was more or less similar. This suggests that BOD

removal is more sensitive to load fluctuations in $\mathrm{CWs}$. $\mathrm{TN}$ and $\mathrm{NH}_{4}-\mathrm{N}$ removals were highly affected due to inlet load fluctuations. $\mathrm{TN}$ and $\mathrm{NH}_{4}-\mathrm{N}$ removal mainly occurs by nitrification coupled with denitrification process in the CW beds. 
Nitrification requires mixing of atmospheric $\mathrm{N}$ with wastewater during treatment pathway. High influent loads might restrict good nitrification which subsequently affects $\mathrm{TN}$ and $\mathrm{NH}_{4}-\mathrm{N}$ purification and removal rates of the $\mathrm{CW}$ system. Along with this, TP purification and removal rates were also sharply decreased when influent TP loads sharply declined than its previous year's loads. This suggests that TP is mainly removed by adsorption and precipitation processes and remains accumulated in the $\mathrm{CW}$ bed for long time. During heavy rainfall and snow melting periods, high hydraulic rates might carry this accumulated phosphorus and subsequently increase TP concentration in effluents. Therefore a proper arrangement of TP removal using covered gravel pits constructed before a CW system could be a better alternative for phosphorus removal from wastewater. Average concentrations of TSS, TP, PO $-\mathrm{P}, \mathrm{TN}$ and $\mathrm{NH}_{4}-\mathrm{N}$ in the effluent of all years were below the discharge limit value of: 150 $\mathrm{mg} \mathrm{L}^{-1}$ for TSS; $8 \mathrm{mg} \mathrm{L}^{-1}$ for TP and $\mathrm{PO}_{4}-\mathrm{P}, 60 \mathrm{mg} \mathrm{L}^{-1}$ for $\mathrm{TN}$ and $\mathrm{NH}_{4}-\mathrm{N}$. However, average $\mathrm{BOD}_{5}$ and $\mathrm{COD}_{\mathrm{Cr}}$ concentrations could not meet the discharge limit value of $120 \mathrm{mg} \mathrm{L}^{-1}$ during 2007 and 2008.

It can be concluded from the present study that hybrid CW system is able to produce compromising results besides high fluctuations in inlet load during treatment of high strength milking parlor wastewater.

\subsection{Acknowledgement}

The authors wish to thank Research Council of Ministry of Agriculture, Forestry and Fisheries (MAFF), Japan, for their support by granting funds for the project. 


\subsection{References}

APHA,1992. Standard methods for examination of water and wastewater. $18^{\text {th }}$ ed. American Public Health Association, Washington, DC.

Arias, C.A., Brix, H., Johansen, N.H., 2003. Phosphorus removal from municipal wastewater in an experimental two-stage vertical flow constructed wetland system equipped with a calcite filter. Wat. Sci. Technol. 48, 5, 51-58.

Brix, H., Arias, C.A., 2005. The use of vertical flow constructed wetlands for onsite treatment of domestic wastewater: new Danish guidelines. Ecol. Eng. 25, 491-500.

Beutel, M.W., Newton, C.D., Brouillard, E.S., Watts, R.J., 2009. Nitrate removal in surface-flow constructed wetlands treating dilute agricultural runoff in the lower Yakima Basin, Washington. Ecol. Eng. 35, 1538-1546.

Chazarenc, F., Maltais-Landry, G., Troesch, S., Comeau, Y., Brisson, J., 2007. Effect of loading rate on performance of constructed wetlands treating an anaerobic supernatant. Wat. Sci. Technol. 56, 3, 23-29.

Cooper, P., Smith, M., Maynard, H., 1997. The design and performance of a nitrifying vertical-flow reed bed treatment system. Wat. Sci. Technol. 35, 5, $215-221$.

Cooper, P., 2005. The performance of vertical flow constructed wetland systems with special reference to the significance of oxygen transfer and hydraulic loading rates. Wat. Sci. Technol. 51, 9, 81-90. 
Hamouri, B.E., Kinsley, C., Crolla, A., 2012. A hybrid wetland for small community wastewater treatment in Morocco. Sustainable Sanitation Practice. $12,22-26$.

Justin, M.Z., Vrhovšek, D., Stuhlbacher, A., Bulc, T.G., 2009. Treatment of wastewater in hybrid constructed wetland from the production of vinegar and packaging of detergents. DESALINATION. 246, 100-109.

Kadlec, R.H., Zmarthie, L.A., 2010. Wetland treatment of leachate from a closed landfill. Ecol. Eng. 36, 7, 946-957.

Kato, K., Moriaka, R., Hosokawa, H., Osada, H., Kanazawa, K., Nozoe, T., 2005. Preliminary studies on hybrid wetland systems for purification of milking parlour wastewater in northern part of Japan, In: Proc. $1^{\text {st }}$ International symposium on wetland pollutant dynamics and control, (WETPOL), Ghent, Belgium. pp. 250-251.

Kato, K., Inoue, T., letsugu, H., Koba, T., Sasaki, H., Miyaji, N., Yokota, T., Sharma, P.K., Kitagawa, K., Nagasawa, T., 2010. Design and performance of hybrid reed bed systems for treating high content wastewater in the cold climate, In: Proc. $12^{\text {th }}$ Internat. Conf. on Wetland Systems for Water Pollution Control, (ICWS), Venice, Italy. pp. 511-517.

Kato, K., Inoue, T., letsugu, H., Koba, T., Sasaki, H., Miyaji, N., Kitagawa, K., Sharma, P.K., Nagasawa, T., 2013. Performance of six multi-stage hybrid wetland systems for treating high-content wastewater in the cold climate of Hokkaido, Japan. Ecol. Eng. 51, 256-263. 
Kadlec, R.H., 2000. The inadequacy of first-order treatment wetland models. Ecol. Eng. 15, 105-119.

Kadlec, R.H. and Knight, R.L., 2006. Treatment Wetlands. CRC Press, Boca Raton, FL. Pp. 893.

Kern, J., 2003. Seasonal efficiency of a Constructed Wetland for treating dairy farm wastewater, In: Mander, Ü., Jenssen, P. (Eds.), Constructed Wetlands for wastewater treatment in cold climates. WIT Press, Southampton, UK. pp.195212.

Moir, S.E., Sym, S.G., Clark, J., McGechan, M.B., Castle,K., 2005. An Experimental Plan for testing Methods of treating Dilute farms Effluents and Dirty Water. Ecol. Eng. 90, 3, 349-355.

Munavalli, G.R., Saler, P.S., 2009. Treatment of dairy wastewater by water hyacinth. Wat. Sci. Technol. 59, 4, 713-722.

Noorvee, A., Poldvere, E., Mandar, U., 2005. The effect of vertical flow filter bed on a hybrid constructed wetland system. Wat. Sci. Technol. 51, 9, 137-144.

Nyquist, J. \& Greger, M., 2009. A field study of constructed wetlands for preventing and treating acid mine drainage. Ecol. Eng. 35, 630-642.

Öövel, M., Tooming, A., Mauring, T., Mander, Ü., 2007. Schoolhouse wastewater purification in a LWA-filled Hybrid Constructed Wetland in Estonia. Ecol. Eng. 29, 17-26.

Serrano, L., Varga, D. De la., Ruiz, I., Soto, M., 2011. Winery wastewater treatment in a hybrid constructed wetland. Ecol. Eng. 37, 5, 744-753. 
Singh, S., Haberl, R., Moog, O., Shrestha, R.R., 2009. Performance of an anaerobic baffled reactor and hybrid constructed wetland treating high strength waste water in Nepal-A model for DEWATS. Ecol. Eng. 35, 654-660.

Sharma, P.K., Takashi, I., Kato, K., letsugu, H., Tomita, K., Nagasawa, T., 2012. Seasonal efficiency of a hybrid sub-surface flow constructed wetland system in treating milking parlor wastewater at northern hokkaido. Ecol. Eng. http://dx.doi.org/10.1016/j.ecoleng.2012.12.054 (In Press)

TRIM Co. Ltd., 2012. Eco-product Supersol made from waste glass bottles, Characteristics and constituents. http://www.trims.co.jp/english/product/ index.html (accessed 04.02.13)

Tszynska, A., Obarska-Pempkowiak, H., 2008. Dependence between quality and removal effectiveness of organic matter in hybrid constructed wetlands. Biores. Technol. 99, 6010-6016.

Vymazal, J., 2011. Long-term performance of constructed wetlands with horizontal sub-surface flow: Ten case studies from the Czech Republic. Ecol. Eng. 37, 1, 54-63.

Vymazal, J., Kröpfelová, L., 2011. A three-stage experimental constructed wetland for treatment of domestic sewage: First 2 years of operation. Ecol. Eng. $37,1,90-98$.

Ye, F., Li, Y., 2009. Enhancement of nitrogen removal in towery hybrid constructed wetland to treat domestic wastewater for small communities. Ecol.Eng. 35, 1943-1053. 